those taking mathematics as an auxiliary to economics or biology, and includes, as an option, statistical method. This is an innovation of the greatest importance. The 'Ordinary' is roughly the present higher school certificate course for a 'Principal' subject, but again statistics may be taken if desired. The 'Further' and 'Higher' are suitable for candidates for university scholarships. Astronomy may be taken instead of some of the more advanced mechanics in the 'Further' course.

The Committee recognizes the great diversity of the needs to be catered for, and has tried to make the syllabuses as flexible as possible. Criticism and comment will be welcomed, and a revised edition of the syllabuses will, if necessary, be issued in the light of experience and of suggestions received. It is hoped that the Oxford and Cambridge Joint Board, the Cambridge Local Examinations Syndicate, and the Cambridge colleges will accept the syllabuses as a basis for their examinations. Approval has already been expressed by the Institute of Actuaries, and it is hoped that other professional bodies and the Services will also find them suitable.

\section{National Museum of Wales}

AN important aspect of the annual report for 1943-44 of the National Museum of Wales is the evidence it provides of a council fully conscious of the Museum's educational function, which even under war-time conditions has been considerably developed. Lectures, demonstrations, special exhibitions, loans to research workers and schools, and the provision of facilities, material and instruction for teachers and students engaged in specialized work are striking examples of the valuable work being carried out by all departments. For the future, the opportunities provided by Section 100 of the 1944 Education Act for closer co-operation between schools and museums have been recognized. Accordingly the Council, in collaboration with the Welsh Department of the Ministry of Education, has already given considera. tion to the matter in relation to Welsh schools. Other authorities responsible for the conduct of museum affairs in a post-war world would do well to note this action. The Council also reports that its Memorandum on Museum and Art Gallery Services in Wales and Monmouthshire (summarized in the 1942-43 Report) has been forwarded to the Minister without Portfolio by the Welsh Reconstruction Advisory Council. With it the latter has sent a communication asking the Minister to give special attention to the importance of extensions to the National Museum being recognized as part of the official schedule of post-war reconstruction work; the provision of Government funds for an open-air museum as an essential auxiliary to the National Museum, and the establishment of a museum grant committee, there being a particular need for a grant for technical assistance to local museums in Wales.

Among the many other activities reported by the Council the following are noteworthy. Department of Botany : continuation of research on atmospheric pollen (see New Phyt., 43, 49, 1944, and Museums J., 44, 145, Dec. 1944). Department of Zoology : completion of a detailed list of all the mammalian remains of historic interest, and the continuation of the bibliographical indexing of Welsh species. Department of Archæology : continuation of survey work on ancient buildings in Monmouthshire, and the preparation of a report on the antiquities of West Gower (at the request of the Ancient Monu- ments Department of the Office of Works). Depart. ment of Geology : the provision (in response to many inquiries on various aspects of geology) of informa. tion relative to raw materials, water supply, drainage and roads. The Museum has made many interesting and valuable acquisitions during the year, and it should be noted that the important collection of Celtic antiquities found in 1943 in a bog near Holy. head, Anglesey, is now in the custody of the Archrological Department. A full bibliography of the publications of the National Museum of Wales is a useful appendix to this report.

\section{Museums and Post-War Educational Developments}

ThE annual report of the Manchester Museum (University of Manchester), while stating that the usual museum activities have been carried on during the year 1943-44, points out that its functions in relation to future educational developments can only be properly fulfilled when provision is made for an increase of technical staff, and for adequate working accommodation. As the report states, these needs are common to museums throughout Great Britain. At the present time, however, there are few or no signs that such needs-together with many otherswill be met in the near future. No doubt the solution of the problem might be hastened if the Ministry of Education were to recognize in a more practical manner the considerable educational potentialities of these institutions. In the meantime, for lack of growing space, a valuable public service is unable to progress beyond its 'germination' stage.

\section{Temperature Control}

ThE lecture on "The Practical Side of Fine Temperature Control" delivered by L. T. Townson and R. Barrington Brock to the Society of Chemical Industry in May of last year is now available in pamphlet form as No. 11 of the review Service to Science issued gratis by Messrs. Townson and Mercer. Ltd., of 390, Sydenham Road, Croydon. The lecture dealt with constant-temperature baths, particularly for medium temperatures, and concentrated attention mainly on water baths, which the authors point out are superior to air baths both because of the low heat capacity of air and also, they say, because its low density gives it little inertia, and enables vortices. with consequent temperature differences, to form more easily. The first matter which the authors stress, and on which they give experimental evidence, is the importance of stirring. They believe that paddle stirrers are not sufficiently effective, and that the whole of the liquid must be caused to flow through the bath; this involves the use of a second chamber of some sort, either entirely separate, or formed within the bath by means of false sides or some similar device. Other points which are discussed in the lecture are the effect of thermostat lag, the advantages and disadvantages of proportional control and the effect of heat losses. It is apparently not always realized that these lead to permanent differences of temperature in the bath. In this connexion, lagging is discussed, and the advantages of reflecting metal sheets as insulation are pointed out.

\section{Biological Unit for Vitamin A}

VrramrN $A$ is unique in that the unit by which it has been defined has been measured with reference to a precursor, $\beta$-carotene, and not to vitamin $A$ itself. This biological unit based on $\beta$-carotene as standard is cumbersome and subject to gross errors. 
Cortain foodstuffs are now required by law to include vitamin $A$, and regulations require that foodstuffs, claiming to contain vitamins, be labelled in units. Manufacturers who to-day handle vitamin A are dependent on the spectroscopic method of assay using the extinction coefficient at 325-328 mu as a linear function of vitamin A activity, and it has boen necessary to adopt a factor to relate the spectroscopic reading with the biological international unit. Such factors have become standardized in Great Britain and in America although at different levels.

$\mathrm{N}$. T. Gridgeman, in "The Estimation of Vitamin A" (Lever Brothers and Unilever, Ltd., 74 ; 1944), assembles and reviews the evidence. He shows that these factors do not rest on a sound scientific basis, due mainly to the occurrence of a number of vitamin A congeners and to the fact that the biological test is very complex ; for example, there is the synergism of vitamins $\mathrm{A}$ and $\mathrm{E}$. $\mathrm{He}$ recommends the, adoption of a new unit based on the spectroscopic assay mothod. A provisional skeleton definition would be "the unit of vitamin $\mathbf{A}$ is that quantity which made up to $100 \mathrm{ml}$. with a specified organic solvent gives a solution having an extinction coefficient at $325 \mathrm{mu}$ of 0.005 ". He adds that "the quest for a new easily messurable physiological criterion of response, sharply graded to increasing dosage, prophylactic or therapeutic, of vitamin A, can be regarded as a fruitful research problem".

\section{Stars of the Southern Skies}

Leaflet No. 188 (Oct. 1944) of the Astronomical Society of the Pacific, by Leon E. Salaneve, gives a simplified star chart and guide to observations with the unaided eye and with field-glasses. It has been compiled in response to numerous requests, from the South Pacific in particular, for star finders, constellation guides, etc., and is specially designed for a latitude $20^{\circ}$ south of the equator. Only those stars are shown which are necessary to suggest the constellation figures, and after learning these the observer's knowledge can be extended with the aid of more complete charts. There is a brief description of the constellations, stars of the first magnitude, and of a few interesting objects such as the Great Nebula in Orion, the Large Magellanic Cloud, etc. The Leaflet will serve a useful purpose for those engaged in military operations who have found themselves under unfamiliar skies.

\section{Association of British Zoologists}

THE Association of British Zoologists, which had not met since January 1939 owing to the War, held its tenth annual general meeting on March 24 in the rooms of the Zoological Society of London. Proceedings opened with a business meeting during the course of which the following elections were made or, having been made by the Oouncil, were confirmed : President, Prof. James Ritchie; Hon. Secretary, Dr. John Smart, British Museum (Natural History), London, S.W.7 ; New Members of Council, Prof. D. L. Mackinnon, Prof. James Gray, Mr. J. C. F. Fryer, Prof. C. H. O'Donoghue and Wing-Commander F. S. Russell ; New Trustees, Mr. J. T. Saunders and Dr. W. E. Swinton. After the business meeting, the Association proceeded to a discussion on the "Post-War Teaching of Zoology in Schools and Universities". This discussion was opened by Dr. C. F. A. Pantin and is reported elsewhere in this issue (see p. 535). In the afternoon, a series of four shorter discussions centring around the general topic of "Some Developments of Post-War Research" was engaged in. The first, on "Marine Investigations", was opened by Dr. E. S. Russell and this was followed by one on "The Work of the Zoological Society" opened by Dr. S. A. Neave. Mr. J. C. F. Fryer opened the next, on "Zoological Interests of the Agricultural Research Council", and the final topic was "Freshwater Investigations", opened by Dr. E. B. Worthington.

\section{Frank B. Jewett Research Fellowships}

Frve Frank B. Jewett Fellowships for research in the physical sciences have been awarded by the American Telephone and Telegraph Co. to Dr. Elliot R. Alexander, Dr. Albert S. Eisenstein, Dr. Kenneth Greisen, Dr. Boris Leaf and Dr. Harry Pollard. The availability of these men to accept their fellowships will depend upon the progress of the War, as each is now engaged in essential war research. Dr. Alexander is at present a research chemist at the du Pont Experimental Station at Wilmington; Dr. Eisenstein is a member of the Radiation Laboratory staff at Cambridge, Mass. ; Dr. Greisen is engaged in war work at Santa Fé, New Mexico; Dr. Leaf is an associate chemist in the Metallurgical Laboratory of the University of Chicago; and Dr. Pollard is a member of the Applied Mathematics Group at Columbia University.

\section{Announcements}

THE following appointments have recently been made in the Colonial Services: D. Sturdy, senior agricultural officer, Tanganyika, to be director of agriculture, Jamaica; E. T. Ward, agricultural superintendent, Windward Islands, to be agricultural officer, Tanganyika ; R. K. Hardy, assistant government chemist, Nigeria, to be government chemist, Nigeria ; D. R. Rosevear, senior assistant conservator of forests, Nigeria, to be conservator of forests, Nigeria.

THE following appointments have been made to the technical staff of Ashe Laboratories, Ltd., 120/2, Victoria Streot, London, S.W.I : Mr. D. I. Duveen now takes charge of the development of full-scale production of amino-scids and protein digests; he has worked in Paris and in London and has published papers, some in collaboration with Dr. J. Kenyon, on problems connected with optical activity and the preparation and isolation of substituted naphthacenes and their photo-oxides. Mr. Duveen will be assisted by Mr. E. G. Hatten, formerly of Glaxo Laboratories, who has had experience in the production of fine chemicals and therapeutic preparations. Mr. H. S. Young, formerly with Messrs. Crosse and Blackwell and C. and E. Morton, Ltd., has been appointed food chemist and will be responsible for the control and development of food preparations manufactured by the Ashe Laboratories. Mr. P. Lewis Smith, iormerly with Messrs. Eli Lily and Co., has been appointed to the pharmaceutical section, where bis long experience in the Far East will be of great assistance in the company's export programme. The new appointments will be under the general direction of Dr. W. E. Gaunt, who is known for his work on amino-acids and protein digests.

ERratum.-The new insecticide described in the communication entitled "Acaricidal Property of a New Insecticide, Hexachlorobenzene" printed in Nature of March 31, p. 393, was wrongly named. The substance referred to is benzene-hexachloride, or $1: 2: 3: 4: 5: 6:$ hexachlorocyclohexane. 